\title{
Evaluation of mercury biotransformation by heavy metal-tolerant Alcaligenes strain isolated from industrial sludge
}

\author{
S. Gupta · J. Nirwan
}

Received: 14 September 2012/Revised: 28 March 2013/Accepted: 14 December 2013/Published online: 9 January 2014

(C) Islamic Azad University (IAU) 2014

\begin{abstract}
Heavy metal pollution affects environment adversely and leads to severe implications for both flora and fauna. In the present work, bacterial strain JS-1 was isolated with tolerance for different metals such as mercury $(\mathrm{Hg})$, lead $(\mathrm{Pb})$, cadmium $(\mathrm{Cd})$, nickel $(\mathrm{Ni})$, arsenic (As), tin $(\mathrm{Sn})$, selenium $(\mathrm{Se})$, zinc $(\mathrm{Zn})$, chromium $(\mathrm{Cr})$ and copper $(\mathrm{Cu})$. JS-1 showed a significant tolerance for mercuric chloride (up to $5,000 \mu \mathrm{g} / \mathrm{g}$ ) along with an efficient metal uptake and transformation. Growth of JS-1 was marginally affected on exposure to high mercury concentration due to acclimatization of the culture towards mercury. No mercury was found in cell-free supernatant after $96 \mathrm{~h}$ of incubation with $500 \mu \mathrm{g} / \mathrm{g}$ and $1,000 \mu \mathrm{g} / \mathrm{g}$ of mercury as an active ingredient. Almost all the mercury was found associated with cell biomass as determined by hydride generation atomic absorption spectroscopy. Only $60 \%$ of mercury was sequestered in bacterial biomass on exposure to 2,000 and 5,000 $\mu \mathrm{g} / \mathrm{g}$ mercury. As a detoxification mechanism, nearly $5 \%$ of sequestered mercury was volatilized by the selected isolate (JS-1). Further X-ray diffraction analysis of deposited silvery grey biomass confirmed biotransformation of sequestered mercuric ions into monovalent mercury $\left(\mathrm{Hg}_{2} \mathrm{Cl}_{2}\right)$, a non-bioavailable form of mercury. Culture was characterized morphologically, physiologically and biochemically. 16S rRNA gene sequence of JS-1 revealed its phylogenetic relationship and $98 \%$ homology with Alcaligenes faecalis, a Gram-negative rod-shaped bacterium.
\end{abstract}

S. Gupta $(\bowtie) \cdot$ J. Nirwan

Department of Microbiology, Mata Gujri College,

Fatehgarh Sahib 140406, Punjab, India

e-mail: sau27282@gmail.com
Keywords Mercury - Biotransformation · Volatilization · Bioremediation

\section{Introduction}

Environment has been deteriorated with the addition of heavy metals in soil and water through natural and anthropogenic activities such as mining and smelting causing severe human health implications (Fitzgerald et al. 2007; Qu et al. 2012). Soils get contaminated by the accumulation of heavy metals and metalloids through emissions from the rapidly expanding industrial areas, mine tailings, disposal of high metal wastes, leaded gasoline and paints, use of fertilizers, animal manures, sewage sludge, pesticides, wastewater irrigation, coal combustion residues, spillage of petrochemicals and atmospheric deposition (Khan et al. 2008; Zhang et al. 2010). Finally, these metals leach into ground water and affect the residential flora and fauna as well as whole ecosystem due to their entry in food chain (Selvin et al. 2009; Nongbri and Syiem 2012). Physicochemical processes, such as adsorption, ion exchange, immobilization, precipitation, and chemical oxidation, reduction or leaching, have long been used for reclamation of heavy metal-contaminated sites. These chemical processes generate large volumetric sludge and increase the costs of remediation process (Rakhshaee et al. 2009; Rojas et al. 2011). Physical processes such as onsite processing or excavation have hazardous effects associated with transportation and migration of contaminants from landfill into an adjacent environment. These techniques are difficult to implement and also adversely affect the valuable components of soils (Wuana and Okieimen 2011). Moreover, these physiochemical techniques used for soil remediation render the land area and 
remove all existing biological activities (Gaur and Adholeya 2004). Bioremediation of heavy metal-contaminated sites through biotransformation of these metals has emerged as an exciting and developing strategy to treat metal contamination, especially in environments that are not accessible to other remediation technologies (Wiatrowski and Barkay 2005; Pathak et al. 2009; Gavrilescu 2010). Different biological systems such as plants, bacteria and fungi are superlative in comparison with that of physical and chemical methods of heavy metal removal (Ilhan et al. 2004; You et al. 2010). Microorganisms has been largely explored for remediation as these are easy to handle and can be easily manipulated genetically for transfer of metal binding and transforming genes (Barkay et al. 2003). Microorganisms possess greater remediation efficiency even at low metal concentrations without producing secondary pollutants (Chen et al. 2005; De et al. 2008). Bacteria have developed several efficient systems including extracellular precipitation; intercellular accumulation; oxidation and reduction reactions; methylation/ demethylation and extracellular detoxification for detoxification of heavy metals (Brierley 1990; Lloyd 2002; Gadd 2010).

Mercury is a potent neurotoxin, global priority pollution and a persistent bioaccumulative metal. It is a highly toxic pervasive pollutant that accumulates in organisms (Perry 2011). Exposure to mercury vapours and methyl mercury causes damage to brain, spinal cord, kidneys, eyes and in more severe cases results in death (Barkay and WagnerDobler 2005). The mercurial waste either goes into the drains or is disposed of along with solid waste causing detrimental effects on human health. Behaviour of these metallic pollutants is largely influenced by changes in natural and anthropogenic environment (Filgueiras et al. 2002). Large number of bacteria has been reported for biotransformation of mercurials as an efficient method for reclamation of the environmental pollution caused by mercury (Nakamura et al. 1999; Takeuchi et al. 2001).

Mercury pollution is creating havoc at large scale, and proper measures to keep pace are not yet implemented. Keeping this in mind, one bacterial isolate (JS-1) with resistance for several heavy metals was explored for the transformation of toxic mercury salts into non-toxic and relatively non-available mercury forms by an active detoxification process.

\section{Materials and methods}

Enrichment and isolation of Hg-tolerant bacteria

Enrichment and isolation of potential bacterial strains was carried out using the method as described by Frischmuth et al. (1993) with slight modifications. Industrial sludge from electroplating industry and soil adjoining industrial drainage were collected and used as such for isolation of bacteria. Five gram of soil and sludge samples were suspended in $100 \mathrm{ml}$ of sterilized Bushnell-Haas broth (BHB), composed of (g/l): magnesium sulphate $0.2 \mathrm{~g}$, calcium chloride $0.02 \mathrm{~g}$, monopotassium phosphate $1.0 \mathrm{~g}$, di-ammonium hydrogen phosphate $1.0 \mathrm{~g}$, potassium nitrate $1.0 \mathrm{~g}$, ferric chloride $0.05 \mathrm{~g}$ supplemented with $5 \mu \mathrm{g} / \mathrm{g}$ of mercuric chloride $\left(\mathrm{HgCl}_{2}\right)$ for enrichment of mercury-tolerant bacteria. Flasks were incubated at $37{ }^{\circ} \mathrm{C}$ on incubator shaker $(120 \mathrm{rpm})$ until growth appeared. A small aliquot was then transferred to the fresh BHB media with increased metal ions concentrations up to $10 \mu \mathrm{g} / \mathrm{g}$ for enrichment of mercury-tolerant bacteria. After sufficient subculturing in mercury-supplemented BHB, a loopful of culture was streaked on tryptone soya agar (TSA) plates for purification of cultures. Plates were incubated under aerobic conditions at $37{ }^{\circ} \mathrm{C}$ for $24 \mathrm{~h}$. Cultures with different colony morphology were streaked on fresh plates at least three times to ensure purity of the isolates. Seven cultures (JS-1 to JS-7) were selected on the basis of different colony morphology on agar plates.

\section{Screening of potential strains}

These bacterial strains were screened for their tolerance to high concentration of mercury as described by Gupta et al. (2012). Axenic cultures were inoculated in BHB containing different concentration of mercuric chloride as an active ingredient (i.e. 25, 50, 75, 100, 250, 500, 1,000, 2,000 and $5,000 \mu \mathrm{g} / \mathrm{g}$ ) and were incubated under aerobic conditions at $37^{\circ} \mathrm{C}$. Tolerance for mercury was monitored by appearance of growth in the form of turbidity in flasks.

\section{Metal tolerance studies}

JS-1 was further explored for its tolerance towards different heavy metals as described previously (Gupta et al. 2012). JS-1 was inoculated into TSB supplemented with different concentrations $(50,100,250$ and $500 \mu \mathrm{g} / \mathrm{g})$ of lead $(\mathrm{Pb})$, cadmium (Cd), nickel (Ni), arsenic (As), tin ( $\mathrm{Sn})$, selenium (Se), zinc $(\mathrm{Zn})$, chromium $(\mathrm{Cr})$ and copper $(\mathrm{Cu})$. Inoculated broth was incubated under aerobic conditions at $37^{\circ} \mathrm{C}$. Tolerance for different heavy metals was monitored by appearance of growth in the form of turbidity in flasks.

Biosequestration and transformation of mercury with associated growth studies

\section{Growth profile}

JS-1 was exposed to different concentrations $(500,1,000$, 2,000 and $5,000 \mu \mathrm{g} / \mathrm{g}$ ) of mercury as an active ingredient 
using $\mathrm{HgCl}_{2}$ in $100 \mathrm{ml}$ of $\mathrm{BHB}$ medium to check impact of mercury on growth of the organism. Two controls were simultaneously maintained, i.e. one having inoculum but without metal (positive control) and other having metal but without inoculum (negative control). Growth was monitored by regular measurements of optical density at $600 \mathrm{~nm}$, every $24 \mathrm{~h}$ for $120 \mathrm{~h}$.

\section{Mercury sequestration}

Sequestration of mercury metal inside the bacterial biomass was examined by taking an aliquot of sample from growth associated experiment after regular intervals of time. Mercury uptake by the isolate was determined after separation of the cells by centrifugation $\left(8,000 \mathrm{rpm}\right.$ at $4{ }^{\circ} \mathrm{C}$ for $10 \mathrm{~min}$ ) from the spent medium followed by acid digestion and subsequent dilution as described previously (Gupta et al. 2010). Cell pellet and supernatant containing mercury were separately acid-digested with premixed concentrated nitric acid $\left(\mathrm{HNO}_{3}\right)$ and perchloric acid $\left(\mathrm{HClO}_{4}\right)$ in 3:1 ratio. The samples were completely digested in COD digester. After digestion, samples were diluted with $0.2 \% \mathrm{HNO}_{3}$ and were subjected to coldvapour AAS analysis.

\section{Hydride Generator Atomic Absorption Spectroscopy (HG-AAS)}

Cold-vapour AAS analysis for estimation of mercury in different fractions was carried out on Shimadzu atomic absorption spectrophotometer AA-6200 with hydride vaporizer generator (HVG1). For mercury, the system was operated under inert conditions maintained with argon gas at flow rate $6 \mathrm{~L} / \mathrm{min}$ throughout the measurement.

\section{Evaluation of mercury volatilization}

Biotransformation of mercury by JS-1 was checked in terms of volatilization after sequestration of mercury as described by Gupta et al. (2010). JS-1 was inoculated in BHB (Hi-media) supplemented with $1,000 \mu \mathrm{g} / \mathrm{g}$ mercuric chloride. The organism was grown in round-bottom flasks with the provision of inlet for fresh air supply and outlet to facilitate the collection of spent air. Fresh sterile air supply was maintained using a steady flow of air with bubbler pumps through pre-sterilized $0.22-\mu$ membrane filters (Whatman, USA). Spent air containing volatilized mercury components was trapped in acidic potassium permanganate (Dzairi et al. 2004). Trapping solution was replaced with fresh solution after every $24 \mathrm{~h}$ up to $72 \mathrm{~h}$. Abiotic controls were maintained under similar conditions in BHB supplemented with mercuric chloride.

\section{XRD analysis}

For evaluation of biotransformation of mercuric chloride, XRD analysis of the biomass associated insoluble silvery grey deposit was performed using a Panalytical X'Pert Pro Powder X-ray diffractometer as described previously (Gupta et al. 2012; Gupta and Bector 2013). Bacterial biomass along with insoluble deposit was collected after centrifugation and was then air-dried in the oven at $50{ }^{\circ} \mathrm{C}$ till no further appreciable change in weight of the biomass. These samples were powdered using pestle mortar. X-ray diffraction pattern of the powder samples was recorded with $\mathrm{Cu} \mathrm{K}_{\alpha}$ radiation $\left(\lambda=1.541 \AA\right.$ ) keeping step size $0.0017^{\circ} \mathrm{s}^{-1}$ in the $2 \theta$ range $20^{\circ}-80^{\circ}$ at generator tension $45 \mathrm{kV}$ and generator current $40 \mathrm{~mA}$. Diffractogram was compared to reference data base obtained from COD-Iorg REV 22182 on the basic of $2 \theta$ values along with specific diffraction lines using Match software designed for powdered X-ray diffraction analysis.

\section{Characterization and identification of JS-1}

On the basis of tolerance capacity and bioaccumulation potential of the isolate in BHB, JS-1 was selected for polyphasic characterization and identification. JS-1 was characterized in terms of morphological and biochemical characteristics along with molecular identification and phylogenetic relatedness with other organisms. Biochemical characterization of JS-1 was carried out using standard protocols as described in Bergey's manual of systematic bacteriology (Krieg and Holt 1984). Molecular characterization was performed after isolation of genomic DNA, amplification of 16S rRNA gene with PCR using universal primers (27F and 1492R) followed by sequencing using standard protocols (Sambrook et al. 1989). The PCR product was sequenced at the DNA sequencing facility, University of Delhi, Delhi, India. Multiple sequence alignment was carried out using BLAST (Altschul et al. 1997) followed by classification using RDP II classifier tools (Cole et al. 2007). For phylogenetic profiling, additional sequences were obtained from GenBank (Benson et al. 2006). Sequences were aligned using Clustal W (Thomson et al. 1994), and phylogenetic analysis carried out using MEGA 5 (Tamura et al. 2011). The tree is drawn to scale, with branch lengths in the same units as those of the evolutionary distances used to infer the phylogenetic tree. The evolutionary distances were computed using the maximum composite likelihood method (Tamura et al. 2004).

\section{Statistical analysis}

All the experiments were carried out in triplicate, and results are presented as mean values along with standard error in the respective figures. 


\section{Results and discussion}

In the present study, tolerance and sequestration of mercury were carried out using BHB media whose composition maintains similar environmental conditions as prevalent in

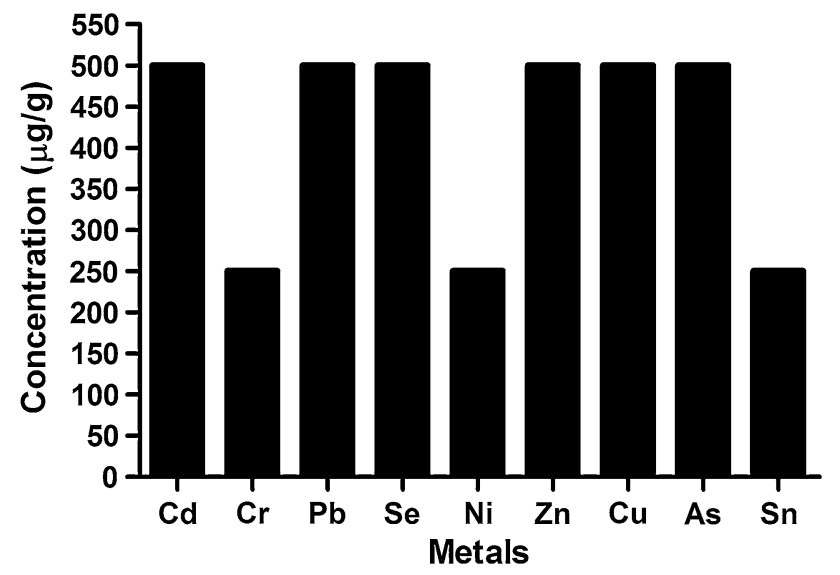

Fig. 1 Multiple metal tolerance profile of JS-1 industrial effluent. Out of seven isolates, JS-1 showed mercury tolerance up to $5,000 \mu \mathrm{g} / \mathrm{g}$ without any significant impact on growth. Hence, JS-1 was selected for subsequent mercury sequestration and transformation studies. Till date, there is no data available for such high tolerance of mercury in aerobic bacteria. Frischmuth et al. (1993) and Ramaiah and De (2003) reported several bacterial strains with tolerance up to $100 \mu \mathrm{g} / \mathrm{g}$ for mercuric chloride in solid and liquid medium.

Multiple metal tolerance

Besides mercury, JS-1 was also observed to exhibit tolerance for several other metals at notably higher concentrations than other organisms reported earlier (Gupta et al. 2012; Mohamed and Abo-Amer 2012). JS-1 tolerated cadmium $(\mathrm{Cd})$, lead $(\mathrm{Pb})$, selenium $(\mathrm{Se})$, zinc $(\mathrm{Zn})$, copper $(\mathrm{Cu})$ and arsenic (As) up to $500 \mu \mathrm{g} / \mathrm{g}$ while tolerance for chromium $(\mathrm{Cr})$, nickel $(\mathrm{Ni})$ and tin $(\mathrm{Ni})$ was comparatively low (up to $250 \mu \mathrm{g} / \mathrm{g}$ ) as indicated by
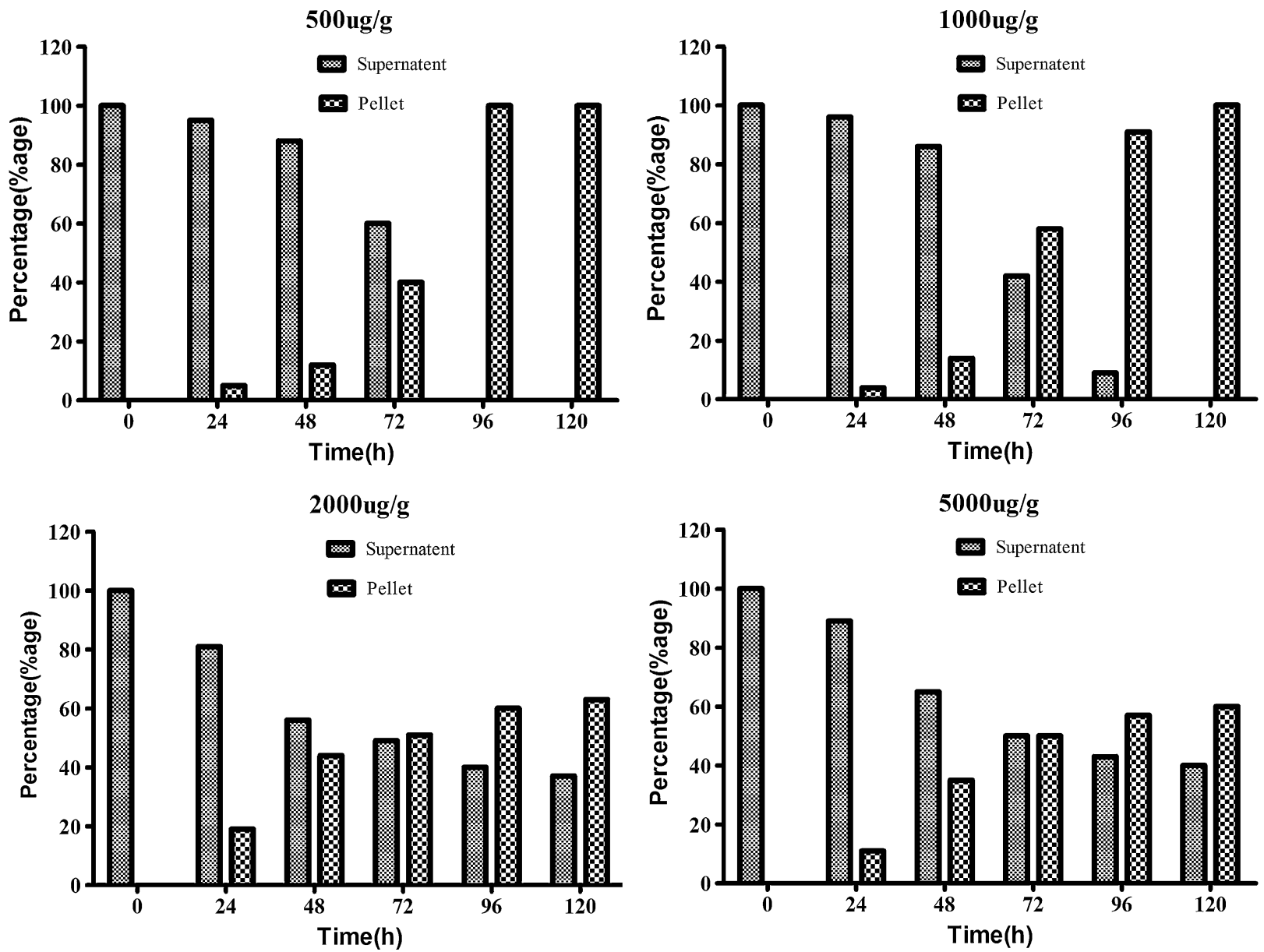

Fig. 2 Mercury sequestration at different concentrations 
growth of culture (Fig. 1). In 2012, Mohamed and AboAmer reported Pseudomonas aeruginosa RA 65 strain, a soil isolate with a significant tolerance for $\mathrm{Cd}, \mathrm{Zn}$ and $\mathrm{Pb}$. Similarly, Gupta et al. (2012) reported multiple metal tolerance in Lysinibacillus fusiformis for different metals. It is speculated from this observation that JS-1 has an indigenous property of metal tolerance for various heavy metals at higher concentrations. Hence, strain JS-1 may be effectively used for bioremediation of metal-contaminated sites.

Mercury confronted metal sequestration and growth studies

\section{Growth profile}

Growth of JS-1 in mercury-supplemented BHB was monitored over a period of $120 \mathrm{~h}$. A marginal increase in lag phase of JS-1 was observed in BHB supplemented with mercury in comparison with growth in positive control.

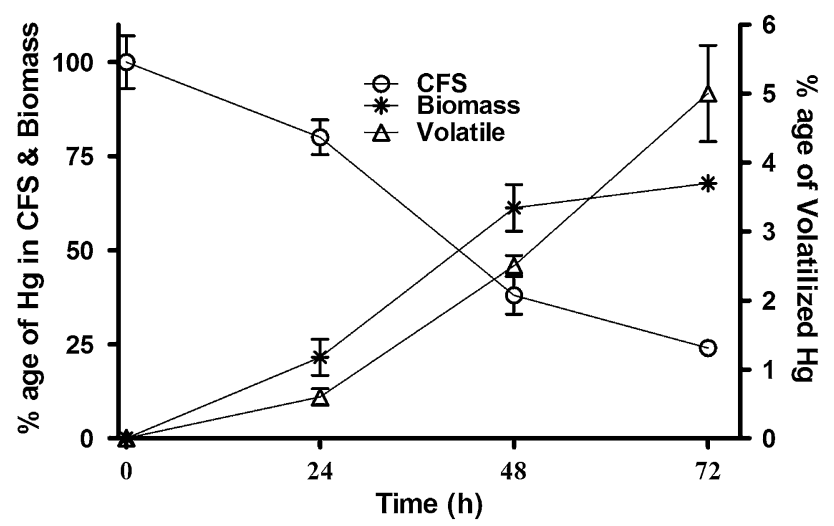

Fig. 3 Percentage of mercury in biomass, cell-free supernatant and trapping solution after $72 \mathrm{~h}$

Table 1 Crystallographic characterization of biomass associated reduced mercury

\begin{tabular}{|c|c|c|c|c|c|c|}
\hline \multirow{2}{*}{$\begin{array}{l}\text { S. } \\
\text { no }\end{array}$} & \multicolumn{3}{|c|}{ Biomass sample } & \multicolumn{3}{|c|}{ Reference sample ${ }^{a}$} \\
\hline & $\begin{array}{l}\text { Pos. } \\
{\left[{ }^{\circ} 2 \mathrm{Th} .\right]}\end{array}$ & $\begin{array}{l}\text { d-spacing } \\
{[\AA]}\end{array}$ & $\begin{array}{l}\text { Rel. } \\
\text { Int. } \\
{[\%]}\end{array}$ & $\begin{array}{l}\text { Pos. } \\
{\left[{ }^{\circ} 2 \text { Th. }\right]}\end{array}$ & $\begin{array}{l}\text { d-spacing } \\
{[\AA]}\end{array}$ & $\begin{array}{l}\text { Rel. } \\
\text { Int. } \\
{[\%]}\end{array}$ \\
\hline 1 & 21.5634 & 4.12 & 70.00 & 21.5634 & 4.14 & 87.30 \\
\hline 2 & 28.2768 & 3.16 & 100.00 & 28.2891 & 3.16 & 77.70 \\
\hline 3 & 32.9322 & 2.72 & 54.43 & 32.9322 & 2.72 & 22.70 \\
\hline 4 & 43.9010 & 2.06 & 28.10 & 43.9010 & 2.06 & 39.00 \\
\hline 5 & 46.3956 & 1.96 & 15.98 & 46.4011 & 1.96 & 21.50 \\
\hline 6 & 53.0524 & 1.72 & 4.02 & 53.0525 & 1.73 & 21.30 \\
\hline 7 & 58.3502 & 1.59 & 6.83 & 58.3502 & 1.59 & 6.83 \\
\hline
\end{tabular}

${ }^{a}$ Havighurst (1926)
There was little or no effect on growth of culture was observed at different concentrations of mercury. Similarly, comparatively good growth in $P$. aeruginosa on exposure to different selenium oxyanions was reported by Gupta et al. (2010). In contrary, Frischmuth et al. (1993) reported significant growth of different isolates at low mercury concentration with a severe reduction in growth at high concentration of mercuric chloride. Growth of these strains (HGS1, HGS2 and HGS4) in the presence of $\mathrm{HgCl}_{2}$ proved high tolerance of these isolates against $\mathrm{Hg}(\mathrm{II})$. Different pathways have been proposed for mercury tolerance and resistance in terms of efflux mechanism where microorganisms expel transformed metal ions outside the cell using energy dependent efflux system (Silver and Walderhaug 1992).

\section{Sequestration studies}

Extensive sequestration of mercury was observed in biomass of JS-1. On exposure to comparatively low concentrations $(500 \mu \mathrm{g} / \mathrm{g}$ and $1,000 \mu \mathrm{g} / \mathrm{g})$ of mercuric chloride, almost $100 \%$ metal accumulation was observed while a significant decrease in sequestration of mercury was observed in JS- 1 at high concentrations $(2,000$ and $5,000 \mu \mathrm{g} / \mathrm{g}$ ) of mercuric chloride (Fig. 2). This may be attributed to the formation of mercurous chloride or organic mercury sulphides inside the cells (Glendinning et al. 2005). In contrary, Frischmuth et al. (1993) reported no mercury in cell suspension due to a detoxification mechanism based on the reduction of $\mathrm{Hg}$ (II) to volatile elemental mercury followed by microbial cells which is less toxic for the microbial cells. Similarly in the present study, growth of JS-1 in presence of high mercury content along with its sequestration is speculated to some detoxification mechanisms harboured by the culture.

\section{Volatilization studies}

Biotransformation of mercuric chloride into elemental mercury was confirmed using volatilization studies along

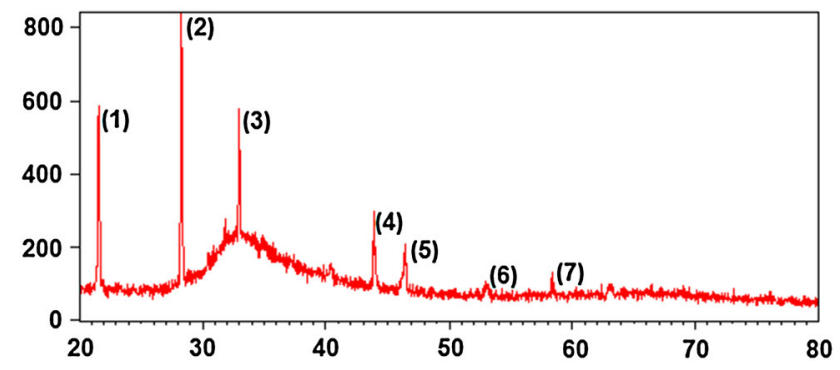

Fig. 4 X-ray diffraction pattern of biomass associated mercury 
with amount of mercury volatilized during transformation of mercury. About $5 \%$ of the mercury was volatilized by the isolate in closed batch system, when subjected to $1,000 \mu \mathrm{g} / \mathrm{g}$ of mercuric chloride after $72 \mathrm{~h}$ (Fig. 3). Gupta et al. (2010) reported 5-7\% volatilization of different selenium oxyanions using $P$. aeruginosa isolated from seleniferous soils. In contrary, Dzairi et al. (2004) and Gupta et al. (2012) reported volatilization of significant proportion of mercuric chloride by Klebsiella pneumoniae and L. fusiformis, respectively. Frischmuth et al. (1993) reported nearly $100 \%$ volatilization of mercury by actively growing mixed bacterial population.
Table 2 Morphological, physiological and biochemical characteristics of the JS-1
Fig. 5 Evolutionary relationships of JS-1 with other taxa using the UPGMA method (Sneath and Sokal 1973). The tree is drawn to scale, with branch lengths in the same units as those of the evolutionary distances used to infer the phylogenetic tree. The evolutionary distances were computed using the maximum composite likelihood method (Tamura et al. 2004). Evolutionary analyses were conducted in MEGA5 (Tamura et al. 2011)

\begin{tabular}{llll}
\hline Characters & Observations & Characters & Observations \\
\hline Morphological & & \multicolumn{2}{l}{ Biochemical characteristics } \\
Cell shape & Rod shape & Indole utilization & $-\mathrm{ve}$ \\
Gram stain & Gram negative & Methyl red & $+\mathrm{ve}$ \\
Colony morphology & Opaque, undulate margin & Voges-Proskauer & $-\mathrm{ve}$ \\
Pigmentation & No pigment & Citrate utilization & $+\mathrm{ve}$ \\
Physiological & & Nitrate reduction & $-\mathrm{ve}$ \\
Growth at $4{ }^{\circ} \mathrm{C}$ & $-\mathrm{ve}$ & $\mathrm{H}_{2}$ S production & $-\mathrm{ve}$ \\
Growth at $42{ }^{\circ} \mathrm{C}$ & $+\mathrm{ve}$ & Urease & $-\mathrm{ve}$ \\
Growth at $45{ }^{\circ} \mathrm{C}$ & $+\mathrm{ve}$ & Starch hydrolysis & $+\mathrm{ve}$ \\
Growth with $1 \% \mathrm{NaCl}$ & $+\mathrm{ve}$ & Casein hydrolysis & $-\mathrm{ve}$ \\
Growth with $5 \% \mathrm{NaCl}$ & $+\mathrm{ve}$ & Lipid hydrolysis & $-\mathrm{ve}$ \\
Growth with $7 \% \mathrm{NaCl}$ & $+\mathrm{ve}$ & Gelatin liquefaction & $-\mathrm{ve}$ \\
Growth with $10 \% \mathrm{NaCl}$ & $+\mathrm{ve}$ & Oxidase & $+\mathrm{ve}$ \\
Growth at $\mathrm{pH}-2$ & $-\mathrm{ve}$ & Catalase & $+\mathrm{ve}$ \\
& & Carbohydrate & \\
Growth at $\mathrm{pH}-5$ & & fermentation test & $-\mathrm{ve}$ \\
Growth at $\mathrm{pH}-8$ & Sucrose & $+\mathrm{ve}$ \\
Growth at $\mathrm{pH}-11$ & $-\mathrm{ve}$ & Glucose & $-\mathrm{ve}$ \\
\hline & $-\mathrm{ve}$ & Lactose &
\end{tabular}




\section{Crystallographic characterization of sequestered $\mathrm{Hg}$}

In the recorded XRD patterns (Fig. 4), out of 10 peaks obtained, seven major peaks at $2 \theta$ values: $21.56^{\circ}, 28.27^{\circ}$, $32.93^{\circ}, 43.90^{\circ}, 46.39^{\circ}, 53.05^{\circ}$ and $58.35^{\circ}$ were matching with reference data (Havighurst 1926) available for calomel (File no. 96-101-1077) (Table 1) were assigned as 1-7 on XRD crystallograph (Fig. 4). Similarly, Gupta et al. (2012) also reported formation of calomel from mercuric chloride using XRD analysis. On the basis of reference data (Havighurst 1926), reduced mercury was assigned to tetragonal crystal lattice of mercurous chloride $\left(\mathrm{Hg}_{2} \mathrm{Cl}_{2}\right)$.

\section{Characterization and identification of JS-1}

Characterization of isolate JS-1 in terms of morphological, physiological and biochemical characteristics was carried out and is depicted in Table 2. The rod-shaped isolate strains Gram-negative, is motile, is a non-spore former and does not produce any pigment. Physiologically, it tolerated a wide range of $\mathrm{pH}$ values (4.0-7.0), a temperature range of $15-45{ }^{\circ} \mathrm{C}$ and a high salt concentration $(10 \mathrm{w} / \mathrm{v} \%)$ (Table 2). The culture was maintained and grown under aerobic conditions, was catalase and was oxidase positive with no nitrate reduction hence considered an obligate aerobe. Analysis of the 16S rRNA gene sequence by multiple sequence alignment (BLAST) indicated $99 \%$ homology to Alcaligenes with alignment coverage over entire sequence (Fig. 5). RDP II classifier was further used to confirm identity of JS-1 to the genus Alcaligenes (Wang et al. 2007). Similarly, a cadmium-tolerant Alcaligenes strain was characterized and identified using 16S rRNA gene sequencing followed by BLAST (Kumar et al. 2012).

\section{Conclusion}

In the present study, one Gram-negative rod-shaped bacterial strain has been isolated from the industrial effluent with a potential to tolerate and grow in presence of mercury up to $5,000 \mu \mathrm{g} / \mathrm{g}$. Culture was characterized morphologically, physiologically, biochemically and phylogenetically. JS-1 is an efficient strain for mercury metal accumulation. Significant reduction and volatilization of mercuric chloride revealed an inherited and indigenous property of the strain towards the transformation of mercuric ions to calomel, an insoluble and non-bioavailable form. Mercurous chloride (calomel) being insoluble in water can be easily collected and utilized in electrochemical industry. JS-1 may be exploited for remediating mercury contamination present in various industrial effluents at larger scale in the near future.
Acknowledgments Author sincerely thanks Shiromani Gurdwara Parbandhak Committee (SGPC), Sri Amritsar Sahib and Dr. Jatinder Singh Sidhu, Director-Principal, Mata Gujri College, Fatehgarh Sahib for providing space and other research facilities in the department for this work.

\section{References}

Altschul SF, Thomas LM, Alejandro AS, Jinghui Z, Zheng Z, Webb M, Lipman DJ (1997) Gapped BLAST and PSI-BLAST: a new generation of protein database search programs. Nucl Acid Res 25:3389-3402

Barkay T, Wagner-Dobler I (2005) Microbial transformations of mercury: potentials, challenges, and achievements in controlling mercury toxicity in the environment. Adv Appl Microbiol $57: 1-40$

Barkay T, Miller SM, Summers AO (2003) Bacterial mercury resistance from atoms to ecosystems. FEMS Microbiol Rev 27:355-384

Benson DA, Karsch-Mizrachi I, Lipmann DJ, Ostell J, Wheeler DL (2006) Gen-Bank. Nucl Acid Res 34(Database issue), D16-D20

Brierley CL (1990) Bioremediation of metal contaminated surface and ground waters. Geomicrobiol J 8:210-223

Chen XC, Wang YP, Lin Q, Shi JY, Wu WX, Chen YX (2005) Biosorption of copper (II) and zinc (II) from aqueous solution by Pseudomonas putida CZ1. Colloids Surf B Biointerfaces 46:101-107

Cole JR, Chai B, Farris RJ, Wang Q, Kulam-Syed-Mohideen AS, McGarrell DM, Bandela AM, Cardenas E, Garrity GM, Tiedje JM (2007) The ribosomal database project (RDP-II): introducing my RDP space and quality controlled public data. Nucl Acid Res 35:D169-D172

De J, Ramaiah N, Vardanyan L (2008) Detoxification of toxic heavy metals by marine bacteria highly resistant to mercury. Mar Biotechnol 10:471-477

Dzairi FZ, Zeroual Y, Moutaouakkil A, Taoufik J, Talbi M, Loutfi M, Lee K, Blaghen M (2004) Bacterial volatilization of mercury by immobilized bacteria in fixed and fluidized bed bioreactor. Ann Microbiol 54:353-364

Filgueiras AV, Lavilla I, Bendicho C (2002) Chemical sequential extraction for metal partitioning in environmental solid samples. J Environ Monit 4:823-857

Fitzgerald WF, Lamborg CH, Hammerschmidt CR (2007) Marine Biogeochemical cycling of mercury. Chem Rev 107:641-662

Frischmuth A, Weppen P, Deckwer WD (1993) Microbial transformation of mercury(II): i. Isolation of microbes and characterization of their transformation capabilities. J Biotechnol 29:39-55

Gadd GM (2010) Metals, minerals and microbes: geomicrobiology and Bioremediation. Microbiology 156:609-643

Gaur A, Adholeya A (2004) Prospects of arbuscular mycorrhizal fungi in phytoremediation of heavy metal contaminated soils. Curr Sci 86:528-534

Gavrilescu M (2010) Environmental biotechnology: achievements, opportunities and challenges. Dyn Biochem Process Biotechnol Mol Biol 4:1-36

Glendinning KJ, Macaskie LE, Brown NL (2005) Mercury tolerance of thermophilic Bacillus sp. and Ureibacillus sp. Biotechnol Lett 27:1657-1662

Gupta S, Bector S (2013) Biosynthesis of extracellular and intracellular gold nanoparticles by Aspergillus fumigatus and A. flavus. Anton Van Leewanhoek 103:1113-1123

Gupta S, Prakash R, Tejoprakash N, Pearce C, Pattrick R, Hery M, Lloyd J (2010) Selenium Mobilization of Pseudomonas 
aeruginosa (SNT-SG1) isolated from seleniferous soils from India. Geomicrobiol J 27:35-42

Gupta S, Goyal R, Nirwan J, Cameotra SS, Prakash NT (2012) Biosequestration, transformation and volatilization of Mercury by Lysinibacillus fusiformis isolated from Industrial effluent. J Microbiol Biotechnol 22:684-689

Havighurst RJ (1926) Parameters in crystal structure. The mercurous halides. J Am Chem Soc 48:2113-2125

Ilhan S, Cabuk A, Filik C, Calikan F (2004) Effect of pretreatment on biosorption of heavy metals by fungal biomass. Trakya Univ $\mathbf{J}$ Sci 5:11-17

Khan S, Cao Q, Zheng YM, Huang YZ, Zhu YG (2008) Health risks of heavy metals in contaminated soils and food crops irrigated with wastewater in Beijing. China Environ Pollut 152:686-692

Krieg NR, Holt JG (1984) In: Murray RGE, Brenner DJ, Bryant MP et al. (eds) Bergey's manual of systematic bacteriology, vol-I. Williams and Wilkins, Baltimore, MD

Kumar A, Gupta S, Cameotra S (2012) Screening and characterization of potential cadmium biosorbent Alcaligenes strain from Industrial effluent. J Basic Microbiol 52:160-166

Lloyd JR (2002) Bioremediation of metals: the application of microorganisms that make and break minerals. Microbiology 29:67-69

Mohamed RM, Abo-Amer AE (2012) Isolation and characterization of heavy-metal resistant microbes from roadside soil and phylloplane. J Basic Microbiol 52:53-65

Nakamura K, Hagimine M, Sakai M, Furukawa K (1999) Removal of mercury from mercury contaminated sediments using a combined method of chemical leaching and volatilization of mercury by bacteria. Biodegradation 10:443-447

Nongbri BB, Syiem MB (2012) Analysis of heavy metal accumulation in water and fish (Cyprinus carpio) meat from Umiam lake in Meghalaya, India. Int Multidis Res J 2:73-76

Pathak A, Dastidar MG, Sreekrishnan TR (2009) Bioleaching of heavy metals from sewage sludge: a review. J Environ Manage 90:2343-2353

Perry E (2011) Beware ongoing mercury pollution in air, water. Pocono record

Qu J, Yan X, Wang X, Shao P, Cong Q (2012) Distribution of heavy metals, chemical fractions and ecological risks around a molybdenum mine in Liaoning Province, China. Vitam Trace Elem 1:104

Rakhshaee R, Giahi M, Pourahmad A (2009) Studying effect of cell wall's carboxyl-carboxylate ratio change of Lemna minor to remove heavy metals from aqueous solution. J Hazard Mater 163:165-173

Ramaiah N, De J (2003) Un-usual rise in mercury-resistant bacteria in coastal environments. Microbial Ecol 45:444-454
Rojas LA, Yanez C, Myriam Gonzalez M, Lobos S, Smalla K, Seeger M (2011) Characterization of the metabolically modified heavy metal-resistant Cupriavidus metallidurans strain MSR33 generated for mercury bioremediation. PLoS ONE 6:e17555

Sambrook J, Fritsch EF, Maniatis T (1989) Molecular cloning: a laboratory manual, 2nd edn. Cold Spring Harbor, New York

Selvin J, Shanmugha PS, Seghal KG, Thangavelu T, Sapna BN (2009) Sponge-associated marine bacteria as indicators of heavy metal pollution. Microbiol Res 164:352-363

Silver S, Walderhaug M (1992) Gene relation of plasmid and chromosome determined inorganic ion transport in bacteria. Microbiol Rev 56:195-228

Sneath PHA, Sokal RR (1973) Numerical taxonomy. Freeman, San Francisco

Takeuchi F, Iwahori K, Kamimura K, Negishi A, Maeda T, Sugio T (2001) Volatilization of mercury under acidic conditions from mercury-polluted soil by a mercury-resistant Acidithiobacillus ferrooxidans SUG2-2. Biosci Biotechnol Biochem 65:1981-1986

Tamura K, Nei M, Kumar S (2004) Prospects for inferring very large phylogenies by using the neighbor-joining method. Proc Natl Acad Sci USA 101:11030-11035

Tamura K, Peterson D, Peterson N, Stecher G, Nei M, Kumar S (2011) MEGA5: molecular evolutionary genetics analysis using maximum likelihood, evolutionary distance, and maximum parsimony methods. Mol Biol Evol 28:2731-2739

Thomson JD, Higgins DG, Gibson TJ (1994) CLUSTALW: improving the sensitivity of progressive multiple sequence alignment through sequence weighting, position-specific gap penalties and weight matrix choice. Nucl Acid Res 22:4673-4680

Wang Q, Garrity GM, Tiedje JM, Cole JR (2007) Naive Bayesian classifier for rapid assignment of rRNA sequences into the new bacterial taxonomy. Appl Environ Microbiol 73:5261-5267

Wiatrowski HA, Barkay T (2005) Monitoring of microbial metal transformations in the environment. Curr Opin Biotechnol $16: 261-268$

Wuana RA, Okieimen FE (2011) Heavy metals in contaminated soils: a review of sources, chemistry risks and best available strategies for remediation, vol 2011. Article ID 402647, 20 pages. International Scholarly Research Network (ISRN) Ecology

You K, Sha M, Fu J, Tang Y, Wang X (2010) Removal of Heavy Metals from Urban Sewage Sludge by Bioleaching. E-Product E-Service and E-Entertainment (ICEEE), International Conference 7-9, 2010

Zhang MK, Liu ZY, Wang H (2010) Use of single extraction methods to predict bioavailability of heavy metals in polluted soils to rice. Commun Soil Sci Plan 41:820-831 